\title{
Socioecological resilience of typical citrus fruit agroecosystems
}

\section{Resiliencia socioecológica de agroecosistemas citrícolas tipificados}
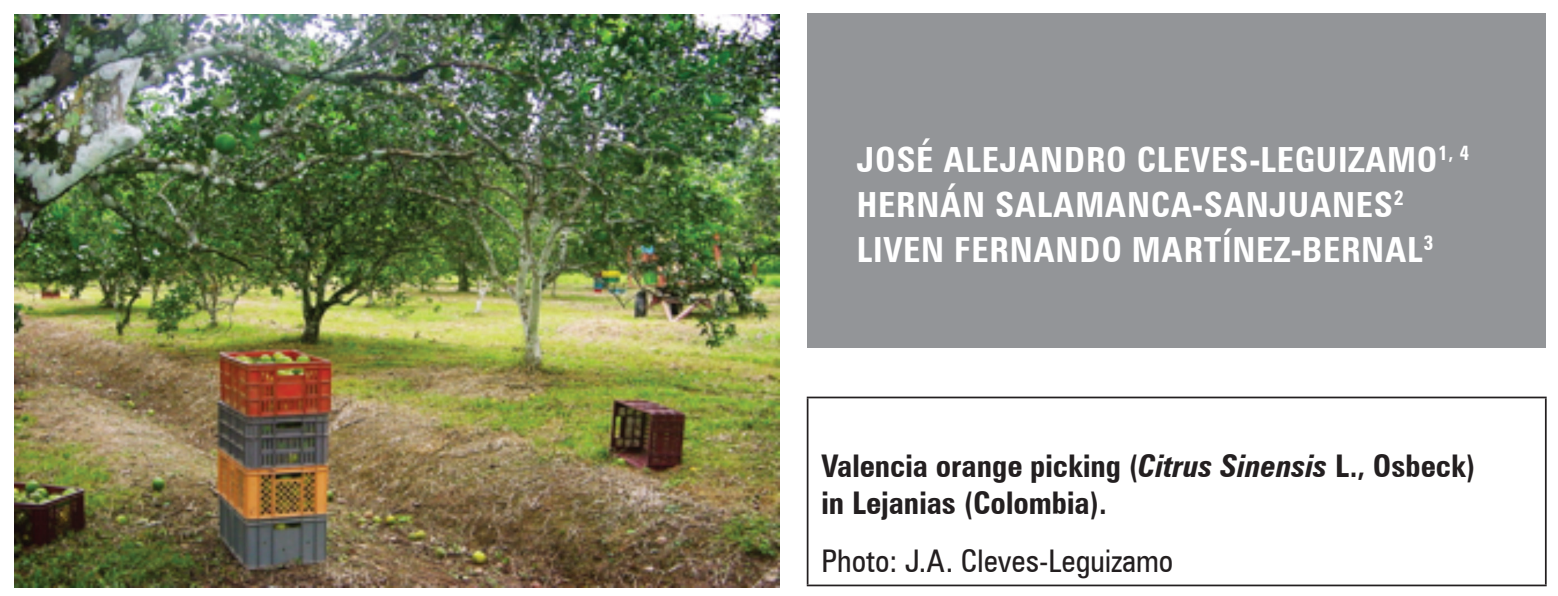

\begin{abstract}
This paper, as a tool for analysis, considered the capacity of the interaction that open systems have against the occurrence of disturbances so that they can continue to function with minimal losses of energy, called resilience, an emerging characteristic of agroecosystems. To establish a method to measure this characteristic, ten variables were evaluated, including seven cultural variables: level of schooling, land tenure type, saving capacity, social organizational identity, farm infrastructure, weed control and production system; and three ecosystem variables: water resource availability, phytosanitary management and Main Agroecological Structure (MAS) in typical citrus fruit agroecosystems. These were methodologically grouped into six recommended domains: groups of farms and citrus growers with similar ecosystem and cultural conditions that have been characterized and typified in a previous study. In each of these groups, three farm types were selected for a total of 18 production units (department of Meta, Colombia). To determine the difference between the variables, Chi-square tests were applied (using the Pearson and Fisher statistics). Network analysis was applied to determine the relationship between the variables. The resilience was not significantly correlated with level of schooling, farm infrastructure or MAS. The relationship between the resilience and cultural variables presented a high significance, whereas the ecosystem variables showed a low statistical significance.
\end{abstract}

\footnotetext{
Additional key words: citriculture; Orinoquía; productive systems; low tropics.

Universidad Pedagógica y Tecnológica de Colombia (UPTC), Duitama Sectional Faculty, School of Agricultural Business Administration, Duitama (Colombia). ORCID Cleves-Leguizamo, J.A.: 0000-0001-9717-9753

2 Instituto de Hidrología, Meteorología y Estudios Ambientales (IDEAM), Subdirección de Estudios Ambientales, Bogota (Colombia). ORCID Salamanca-Sanjuanes, H.: 0000-0002-6031-8884

3 Universidad Nacional de Colombia, Instituto de Estudios Ambientales (IDEA), Bogota (Colombia).ORCID MartínezBernal, L.F.: 0000-0002-2117-3715

4 Corresponding author. jose.cleves@uptc.edu.co
} 


\section{RESUMEN}

En este artículo, como una herramienta de análisis se consideró la capacidad de interacción que tienen los sistemas abiertos frente a la ocurrencia de un disturbio, de tal manera que puedan seguir funcionando con mínimas pérdidas de energía e información, denominada resiliencia y es considerada como una característica emergente de los agroecosistemas. Con el objetivo de establecer un método para medir esta característica se evaluaron diez variables, siete culturales: nivel de escolaridad, tipo de tenencia de la tierra, capacidad de ahorro, pertenencia a alguna organización social, infraestructura de la finca, control de arvenses y sistema de producción; y tres variables ecosistémicas: disponibilidad del recurso hídrico, manejo fitosanitario y Estructura Agroecológica Principal (EAP) en agroecosistemas citrícolas tipificados. Estas variables fueron agrupadas metodológicamente en seis dominios de recomendación, es decir grupos de fincas y de citricultores con condiciones ecosistémicos y a la vez culturales similares, que en trabajo previo habían sido caracterizados y tipificados. En cada uno de estos grupos se seleccionaron tres fincas tipo para un total de 18 unidades productivas (Meta, Colombia). Para determinar diferencia entre las variables se aplicaron pruebas de Chi Cuadrado (empleando los estadísticos de Pearson y Fisher). Para determinar la relación entre las variables se aplicó análisis de redes, pudiéndose determinar que el nivel de escolaridad, infraestructura de la finca y EAP no presentaron relación de significancia con la resiliencia. La relación entre las variables culturales presentaron una alta significancia, mientras que las variables ecosistémicas evidenciaron baja significancia estadística con la resiliencia.

Palabras clave adicionales: citricultura; Orinoquía; sistemas productivos; Trópico bajo.

Received for publication: 24-08-2018 Accepted for publication: 31-07-2019

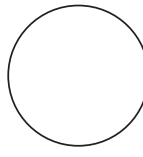

INTRODUCTION

In Latin America, climate variability and extreme events have impacted different regions (Altieri et al., 2012). In this same region, the intensity and presence of extreme events is increasing, and, in Colombia, located in an area with a direct influence from the warming of the Pacific waters, the impact is much stronger than in any other country in the region (PNUD, 2011).

In our country, the temperature regime is determined by its geographical position and its physiographic characteristics (Pabón and Hurtado, 2002). In the Orinoquía region, the distribution of the average air temperature is very uniform, with values ranging from 24 to $28^{\circ} \mathrm{C}$. In contrast, pluviometric variations are significant (Pabón et al., 2001).

In previous studies, the wide genetic plasticity of the Orange Valencia (Citrus sinensis L., Osbeck) was demonstrated for the environmental conditions of the Colombian Orinoquia (Cleves-Leguizamo, 2018a).

This study aimed to give continuity to the analysis of the incidence of the cultural components associated with the production of citrus fruits in the Department of Meta, a place with adequate soil and climate conditions for citrus production (Orduz and Mateus, 2012).
This situation is more significant if we take into account that, in the last decade, the domestic market has shown signs of a citrus shortage as a result of the lower production generated by extreme weather events and deterioration of crops, which has led to a reduction in production (Aguilar et al., 2012). It is necessary to increase the planted area by 15.000 ha, in addition to replacing at least 20,000 ha that have finished their production cycle (Mateus et al., 2010).

Citrus fruits are permanent crops, which require long-term decisions aimed at the sustainability of productive systems (Cleves-Leguizamo et al., 2012). This makes it necessary to understand the effects of human interventions on nature, the transformation of the ecosystem and the impact that such alterations have on communities (Maya, 2003; Nicholls and Altieri, 2012).

The concept of resilience was initially a contribution from the field of Ecology, defined as a system's capacity to persist in the face of disturbances, while keeping its original structure and function stable. This is achieved through learning, adaptation and self-organization processes considered critical characteristics for recovering equilibrium and system control (Holling, 2001). 
To assess resilience in socio-ecological systems, it is necessary to understand and evaluate the dynamic relationship established between human beings and the environment, taking into account ecological and cultural dimensions, including institutions and social capital, as well as leadership ability and community organization (Jiggins and Rolling, 2000).

In this document, resilience is understood as the ability of a system to absorb disturbances, adapt and reorganize. This is done by fulfilling essential productive functions such as food, fiber and ecosystem services, while preserving the system's structure, identity and interactions with the environment (Cleves-Leguizamo, 2018a).

According to Folke (2006) and Walker et al. (2004), resilience has four components: i) Resistance: ease or difficulty of systemic change; ii) Latitude: maximum point of resistance at which a system can respond before losing its resilience; iii) Precariousness: proximity to the system's critical threshold and iv) Panarchy: derived from the interactions between the previous components.
Given that the agroecosystem is both an ecosystem and cultural complex, resilience also extends to the social context. It is therefore understood as the ability of human groups to cope with not only environmental changes but those generated by social, political, economic and commercial factors (Adger, 2000). This socio-ecosystem resilience is made explicit in communities that depend on ecological and environmental resources for their livelihood, as is the case with agroecosystems (Farhad, 2012).

The importance of studying cultural and ecological variables associated with the resilience of citrus agroecosystems implies considering some basic concepts such as: i) Biotope: the physicochemical characteristics of water, soil and atmospheres; ii) Biocenosis: the set of organisms that are related to each other and that collectively depend on the environment (Toledo, 1990); iii) Ecosystem: the complex and dynamic relationship established between organisms and physical elements of a place, giving rise to a functional unit (MEA, 2005), with energy flows and nutrient cycling that make interdisciplinary approaches necessary for describing its structure and function (Hart,

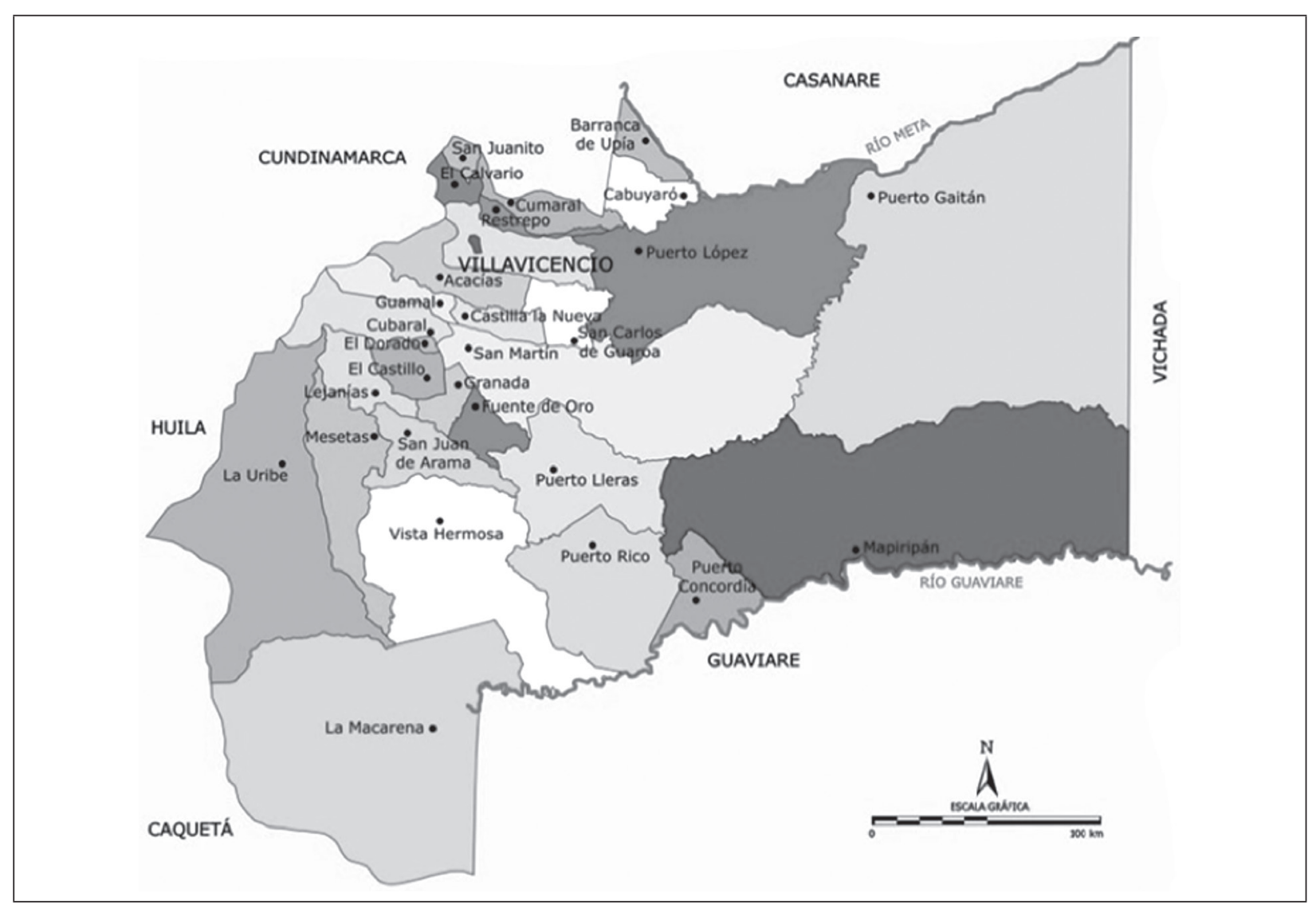

Figure 1. Location of study area municipalities. Source: IGAC (2004). 
1985); and iv) Agroecosystem: multiple relationships and interactions between cultural and ecosystem elements such as soil, plants and organisms at different trophic levels, with diffuse limits that transcend the geographical scope of the crop or farm. The latter (agroecosystems) are considered by some authors as the object of studies with the science of agroecology, which demands a systemic analytical approach (León and Altieri 2009; León, 2010; León, 2012).

This paper aimed to analyze the relationship between resilience and an array of ecosystem and cultural attributes, with resilience defined as the emerging capacity of non-equilibrium systems to respond to varied disturbances. For this specific case, this study was undertaken in citrus production systems located in the Department of Meta, Colombia.

\section{MATERIALS AND METHODS}

The present study was carried out in the municipalities of Villavicencio, Granada, Guamal and Lejanías, where the Department of Meta (Colombia) concentrates $89 \%$ of its planted area and $95 \%$ of its citrus production (SDA, 2016) (Fig. 1).

A survey was designed with the collaboration of community members, unions, technicians and farmers. The primary data were used to structure an Excel database and to conduct a multivariate statistical analysis, resulting in six "domains of recommendation" for the dendrogram, i.e. six farmer groups with similar internal attributes and external heterogeneity (Cleves-Leguizamo and Jarma-Orozco, 2014) (Fig. 2).

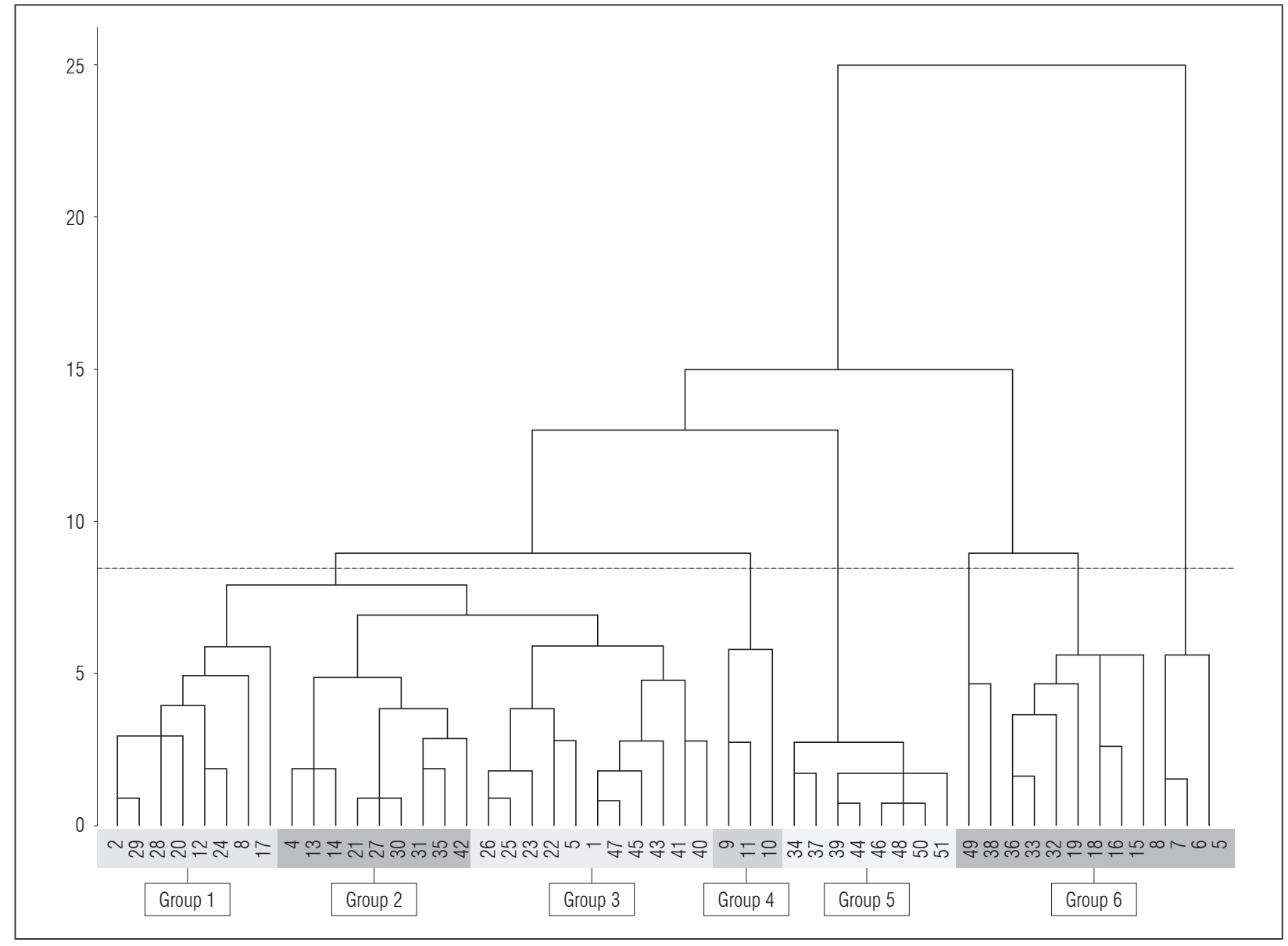

Figure 2. Dendrogram, six recommendation domains. Source: Cleves-Leguizamo and Jarma-Orozco (2014). 


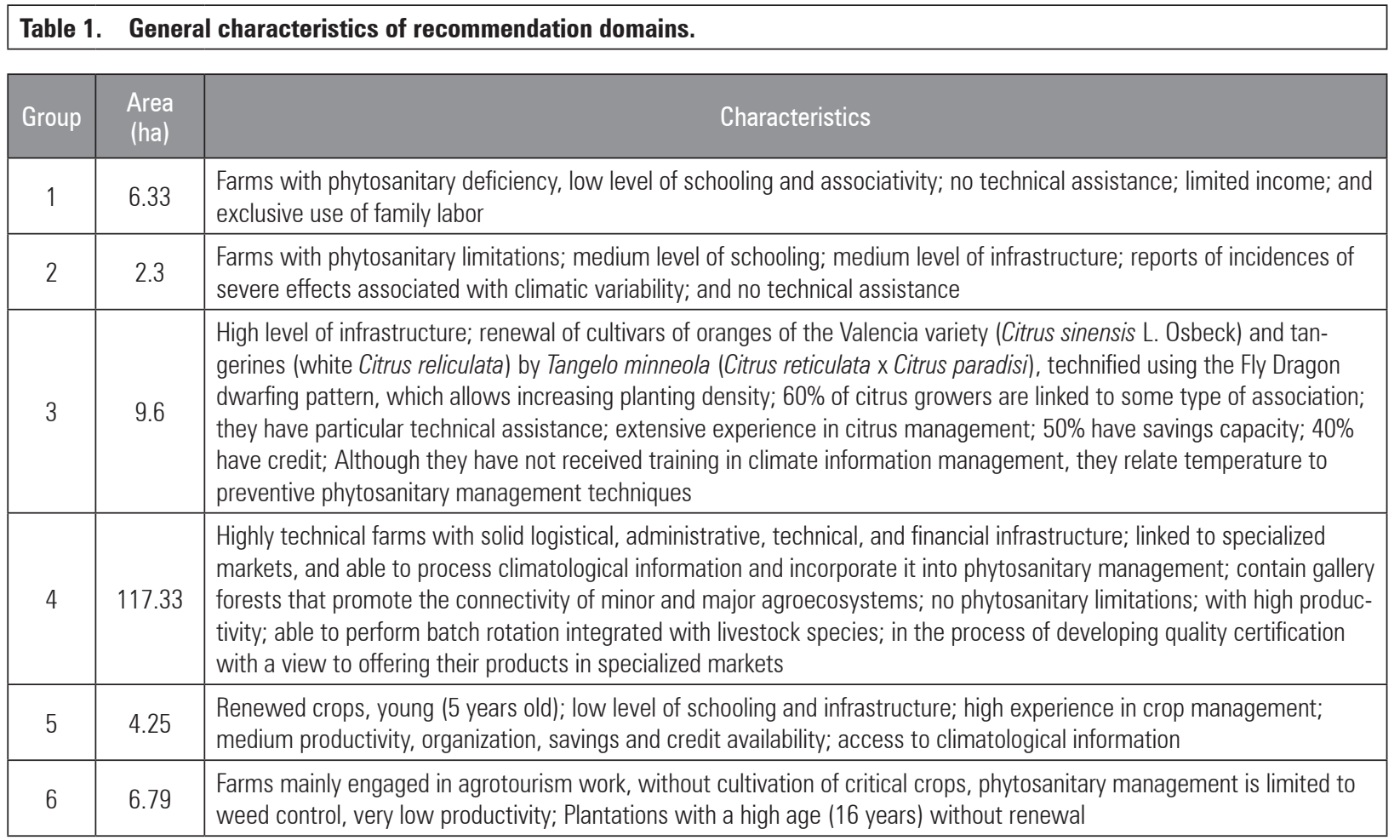

Source: Cleves-Leguizamo and Jarma-Orozco (2014).

The most important attributes were established by Cleves-Leguizamo and Jarma-Orozco (2014); the most relevant ecosystem and cultural attributes of the six groups of citrus growers are presented below (Tab. 1).

To define the variables used to determine resilience, experts in citrus cultivation in the Orinoquia region were consulted. The prioritized variables were the following: 1) education level, 2) type of land tenure, 3) savings capacity, 4) belonging to a social organization, 5) farm infrastructure, 6) water resource availability, 7) phytosanitary crop assessment, 8) weed control, 9) type of production system and 10) Main Agroecological Structure (MAS). Three farms were chosen from each of these groups because of the minimum number of repetitions in the experiment design. The farms were then numbered randomly from 1 to 18 (Tab. 2).

In order to determine the relationship between the variables and resilience from this sampling population, statistical tests including Chi Square, Pearson and Fisher were carried out. Next, a network of interactions was constructed between the analyzed attributes.
Table 2. Groups and associated farms.

\begin{tabular}{|c|c|}
\hline Group & Number of associated farms \\
\hline 1 & 1,2 and 3 \\
\hline 2 & 4,5 and 6 \\
\hline 3 & 7,8 and 9 \\
\hline 4 & 10,11 and 12 \\
\hline 5 & 13,14 and 15 \\
\hline 6 & 16,17 and 18 \\
\hline
\end{tabular}

An estimate for resilience was made applying the methodology proposed by the Ibero-American Network of Agroecology for the Development of Agricultural Systems Resilient to Change, REGRADES (Henao, 2013), using the indicated variables (Tab. 3).

\section{Data analysis}

The results of the 10 variables prioritized in the expert consultation established a measurement of resilience. These measurements were analyzed by group (treatment) and at the farm level (treatment repetitions) 
to determine which variables explained the variation in the resilience to a greater extent. The following procedures were followed:

\begin{tabular}{|c|c|c|c|}
\hline Table 3 & $\begin{array}{l}\text { Variables used in the measure } \\
\text { logical resilience. }\end{array}$ & nent of socio & -eco- \\
\hline Group & Variables & Categories & Value \\
\hline \multirow{3}{*}{1} & \multirow{3}{*}{ Education level (NIDES) } & Primary & 1 \\
\hline & & Secondary & 3 \\
\hline & & University & 5 \\
\hline \multirow{2}{*}{2} & \multirow{2}{*}{ Type of land tenure (TEDLT) } & Landowner & 5 \\
\hline & & Renter & 1 \\
\hline \multirow{2}{*}{3} & \multirow{2}{*}{ Savings capacity (CAPDA) } & Yes & 5 \\
\hline & & No & 1 \\
\hline \multirow{2}{*}{4} & \multirow{2}{*}{$\begin{array}{l}\text { Belonging to a social organization } \\
\text { (TIDOR) }\end{array}$} & Yes & 5 \\
\hline & & No & 1 \\
\hline \multirow{4}{*}{5} & \multirow{4}{*}{ Farm infrastructure (INDLF) ${ }^{*}$} & High & 5 \\
\hline & & Medium & 4 \\
\hline & & Low & 3 \\
\hline & & Poor & 1 \\
\hline \multirow{2}{*}{6} & \multirow{2}{*}{ Water resource availability (FDAPR) } & Yes & 5 \\
\hline & & No & 1 \\
\hline \multirow{4}{*}{7} & \multirow{4}{*}{$\begin{array}{l}\text { Phytosanitary crop assessment } \\
\text { (EVSDC) }\end{array}$} & Excellent & 5 \\
\hline & & Good & 4 \\
\hline & & Fair & 3 \\
\hline & & Poor & 1 \\
\hline \multirow{4}{*}{8} & \multirow{4}{*}{ Weed control (CODAR) } & Excellent & 5 \\
\hline & & Good & 4 \\
\hline & & Fair & 3 \\
\hline & & Poor & 1 \\
\hline \multirow[t]{2}{*}{9} & \multirow[t]{2}{*}{ Type of production system (SIDPR) } & $\begin{array}{l}\text { Monocul- } \\
\text { ture }\end{array}$ & 1 \\
\hline & & Associated & 5 \\
\hline \multirow{4}{*}{10} & \multirow{4}{*}{$\begin{array}{l}\text { Main Agroecological Structure } \\
\left(\text { MAS) }{ }^{* *}\right.\end{array}$} & High & 5 \\
\hline & & Medium & 4 \\
\hline & & Low & 3 \\
\hline & & Nonexistent & 1 \\
\hline
\end{tabular}

* Related to planting activities. ${ }^{*}$ Main Agroecological Structure (MAS), is a methodological instrument for the evaluation of agricultural systems. It has ten components and was originally proposed by León (2012) and later evaluated by Cleves-Leguizamo et al. (2017) as a planning instrument for land use in agroecosystems. Its relevance for permanent crops has also been evaluated by León-Sicard et al. (2018) as well as Cleves-Leguizamo et al. (2018b).

\section{Characterization of the sample using relative frequencies of each of the responses given by the producers}

Use of the REDAGRES methodology to aggregate resilience variables using simple, weight-free averages, which corresponded with survey responses that included environmental and cultural aspects associated with citric agroecosystems. Each variable was assigned a grade based on its condition (optimum, average and low), determining adjustment for lowgraded variables, improvement for average-level variables and conservation for optimally graded variables (Altieri and Nicholls, 2013).

1) Development of contingency tables: resilience per group and resilience per 10 variables.

2) Chi-squared and Fisher's exact test to analyze the relationships between the 10 variables.

3) Summary of the 72 chi-squared and Fisher's exact test results to analyze the relationships between the 10 variables.

4) Construction and analysis of the adjacency matrix of the 10 variables, utilizing the software UCINET (Borgatti et al., 2002).

5) Elaboration of a network diagram using NETDRAW (Borgatti et al., 2002).

\section{RESULTS AND DISCUSSION}

With the purpose of establishing whether the methodology proposed for the estimation of socio-ecological resilience was affected by the general characteristics that were used in the classification (group of farms) and by the type of management implemented at the level of the productive unit (farm), the resilience value was established by farm and by group. For the interpretation of the result, a resilience scale was defined with five categories (Tab. 4).

This proposal of analysis and interpretation established that the methodology used for the calculation of resilience is adequate for the production conditions of citrus fruits in the Department of Meta from the point of view of experiment design, where the groups of farms act as "treatments" and farms are "repetitions" of these treatments. 
Table 4. Ranges proposed for the characterization of socioecological resilience values.

\begin{tabular}{|c|c|}
\hline Range & Interpretation of resilience \\
\hline $4.1-5.0$ & Very high \\
\hline $3.1-4.0$ & High \\
\hline $2.1-3.0$ & Medium \\
\hline $1.1-2.0$ & Low \\
\hline $0.0-1.0$ & Very low \\
\hline
\end{tabular}

The values were also used to determine the relationship between the variables and socio-ecological resilience in order to establish which of them contribute most to explaining the variation in resilience. Below are the general results of the sample (section 3.1.), the results by group (3.2.) and by farm (3.3.), the qualitative analysis of the variables (3.4.), the contribution of these variables to the total value of resilience (3.5.) and, finally, the relationship between the variables and resilience (3.6.).

\section{Characterization of the sample}

The sample was characterized by determining relative frequencies of responses (Tab. 5) for surveys conducted on eighteen farms.
In general terms, the farmers have a low to medium educational level, at least from the point of view of formal education. In relation to income, $66 \%$ of the population has savings capacity. With respect to organizations, $60 \%$ do not belong to any type of organization that facilitates social articulation in any way (Aguilar et al., 2010).

$70 \%$ of the properties are managed directly by their owners, have a medium to high level farm infrastructure, and have established a monoculture production system; $83 \%$ have access to irrigation water, perform good pest management through phytosanitary evaluation and most control weeds with mixed media (mechanical and chemical). None report adopting hedges for this purpose. Finally, the main agroecological structure of the farms included in the study is between medium and low (Cleves-Leguizamo, 2018a).

The conjugation of previous environmental and cultural characteristics determined the socio-ecological resilience (Reay, 2019).

\section{Resilience / group determination}

To determine the resilience of the six analyzed groups, average values were calculated for each of the three farms in each group (Fig. 4).

\section{Table 5. Relative frequencies of survey responses.}

\begin{tabular}{|l|l|}
\hline \multicolumn{1}{|c|}{ Variable } & \multicolumn{1}{|c|}{ Consolidated survey results } \\
\hline Education level & $\begin{array}{l}50 \% \text { possess a low level of education (primary), 27.78\% medium level and 22.22\% possess a high } \\
\text { level of education }\end{array}$ \\
\hline Type of land tenure & $16.67 \%$ rent land, 83.33\% are landowners \\
\hline Savings capacity & $66.67 \%$ possess savings capacity, 33.33\% do not have excess income and are unable to save \\
\hline Belonging to a social organization & $55.56 \%$ do not belong to any association or organization, 44.44\% belong to an organization \\
\hline Farm infrastructure & $\begin{array}{l}22.22 \% \text { have deficient farm structure, 27.78\% have a low level of structure, 11.11\% medium level } \\
\text { and 38.89\% high level }\end{array}$ \\
\hline Water resource availability & $83.33 \%$ have a water source for irrigation, 16.67\% do not have a water source \\
\hline Phytosanitary crop assessment & $\begin{array}{l}11.11 \% \text { of farms have an excellent level of crop assessment; 38.89\% good; 27.78\% fair and 22.22\% } \\
\text { poor }\end{array}$ \\
\hline Weed control & $\begin{array}{l}5.56 \% \text { perform mechanical weed control, 27.78\% perform chemical control and 66.67\% perform } \\
\text { mixed weed control }\end{array}$ \\
\hline Type of production system & $33.33 \%$ have an associated system of production, 66.67\% are monoculture \\
\hline Main Agroecological structure & $\begin{array}{l}16.67 \% \text { have a high main agroecological structure; 33.33\% medium; 33.33\% low; } 16.67 \% \\
\text { nonexistent }\end{array}$ \\
\hline
\end{tabular}




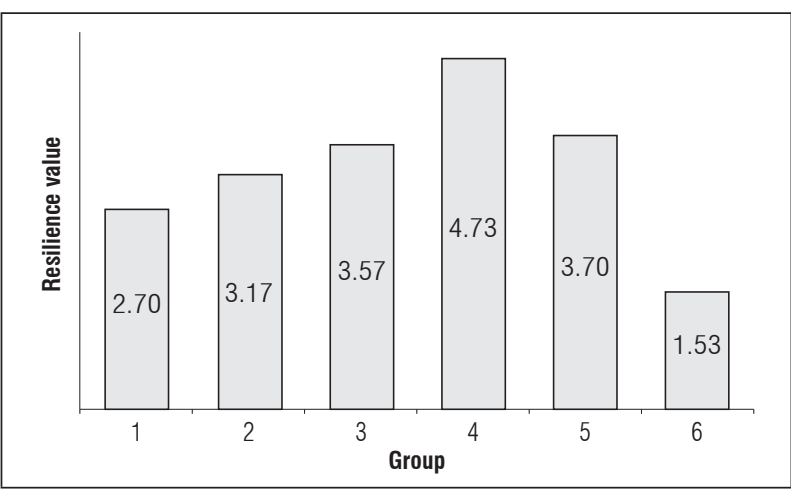

Figure 4. Average values of socioecological resilience for farm groups.

As indicated above, the farms with an agro-industrial productive approach (group 4) have the highest resilience (4.7) since ecosystem and cultural variables offer the best conditions to face externalities; they have a greater capacity to respond to negative events and a greater capacity to capitalize on positive events (Adger, 2000).

Group 6 (resilience of 1.5), on the other hand, had the lowest value and, therefore, will not be able to recover in the face of negative socio-ecosystem externalities and will not be able to take advantage of positive externalities. Group 1 had an equally low resilience value (2.7). Two groups were placed at an intermediate level of resilience (3.6 for group 3 , and 3.7 for group 5), which had a medium capacity to face adverse externalities.

These results showed that the general characteristics that were taken as references for the typification of the groups (Tab. 1) significantly affected the socioecological resilience (Cleves-Leguizamo and JarmaOrozco, 2014). The results of the statistical tests confirmed this statement (Tab. 7).

\section{Resilience by farm}

Resilience was determined based on the average of the values of each of the selected variables and associated with each of the eighteen (18) citrus agroecosystems values (Fig. 5).

The highest values of resilience were observed on farms 10, 11 and 12. These three farms made up the group linked to agribusiness, integrating plant and animal species (major and minor), with gallery forests articulated to biological corridors (León-Sicard,

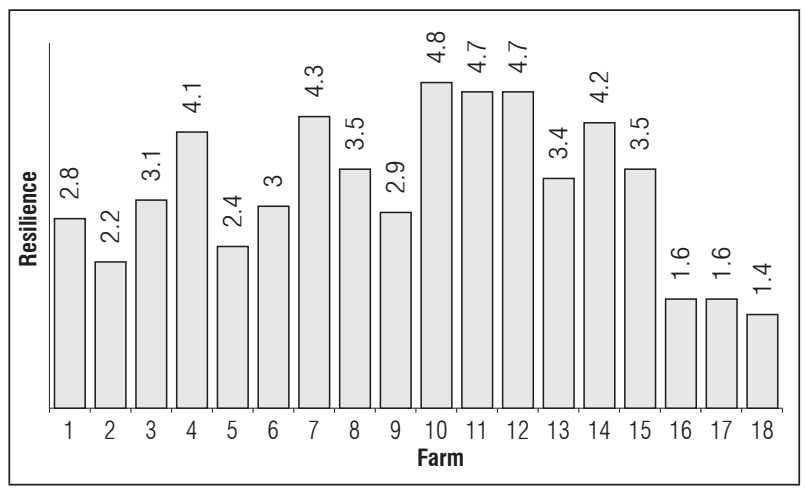

Figure 5. Resilience values obtained per farm.

2018). Administratively, these farms are developing quality certification processes to offer their products in specialized markets. Farms 16, 17 and 18 had the lowest resilience values and belonged to group number 6 , which had plantations that have not been renewed for more than 25 years and only carry out weed control by the owners. These farms have developed tasks linked to agritourism (Aguilar et al., 2012).

On the other hand, farms 1, 2, 3, 5 and 9 had resilience values slightly higher than the previous group and were monocultures, which do not have technical assistance with phytosanitary control that is low efficiency. Finally, farms 4, 6, 7, 8, 13, 14 and 15 presented resilience values between medium and high, associated with a better phytosanitary crop management and access to technical assistance.

\section{Relationship between the variables and resilience}

Although it is pertinent to know the values of the socio-ecosystem resilience of farms and groups, it is necessary to know the relationships between the variables that constitute it. For this reason, to determine the relationship between the variables and the category of resilience, a combination of Pearson's Chi Squared and Fisher's exact tests were performed with a 95\% confidence level in order to avoid possible biases as a result of the sample size. Fisher's exact test was used when the samples were small and the assumption of a minimum expected value equal to 5 of the Pearson Chi-square tests was not met.

In all cases, the null hypothesis established no relationship between the variables. Therefore, values below 0.05 , in asymptotic and/or exact significance, established that there were statistically significant relationships between the variables (Tab. 6). 
Table 6. Results obtained for the statistical tests used to establish the relationship between the variables and the resilience of the farm.

\begin{tabular}{|l|c|c|c|c|c|c|}
\hline \multicolumn{1}{|c|}{ Test } & \multicolumn{3}{c|}{ Pearson's Chi-squared test } & \multicolumn{3}{c|}{ Fisher's exact test } \\
\hline Variables & Value & $\begin{array}{c}\text { Asymptotic } \\
\text { significance }\end{array}$ & $\begin{array}{c}\text { Is the relationship } \\
\text { significant? }\end{array}$ & Value & $\begin{array}{c}\text { Exact } \\
\text { significance }\end{array}$ & $\begin{array}{c}\text { Is the relationship } \\
\text { significant? }\end{array}$ \\
\hline Education level & 10.575 & 0.102 & No & 9.316 & 0.087 & No \\
\hline Type of land tenure & 18 & 0 & Yes & 10.822 & 0.001 & $\mathrm{Si}$ \\
\hline Savings capacity & 8.025 & 0.045 & Yes & 7.472 & 0.037 & $\mathrm{Si}$ \\
\hline Belonging to a social organization & 11.723 & 0.008 & Yes & 11.068 & 0.004 & $\mathrm{Si}$ \\
\hline Farm infrastructure & 16.723 & 0.053 & No & 12.101 & 0.095 & $\mathrm{No}$ \\
\hline Availability of water resources & 7.44 & 0.059 & No & 5.406 & 0.051 & $\mathrm{No}$ \\
\hline Phytosanitary management & 20.537 & 0.015 & Yes & 13.722 & 0.024 & $\mathrm{Si}$ \\
\hline Weed control & 15.48 & 0.017 & Yes & 13.151 & 0.004 & $\mathrm{Si}$ \\
\hline Production system & 18 & 0 & Yes & 15.661 & 0 & $\mathrm{Si}$ \\
\hline MAS & 15.55 & 0.077 & No & 11.16 & 0.177 & $\mathrm{No}$ \\
\hline Group relations & 31.8 & 0.007 & Yes & 19.647 & 0.012 & $\mathrm{Si}$ \\
\hline
\end{tabular}

\section{Qualitative analysis of variables}

The Education level variable did not present a significant relationship with resilience, mainly because of the vast experience that farmers have in crop management (Aguilar et al., 2010). The Type of land tenure presented a significant relationship with resilience. This indicates that the owners who have developed rooting processes and who know their environment better have a greater sense of belonging that is evidenced in the management of the farm (Mateus et al., 2010).

Savings capacity is related to resilience, which means that people with a greater availability of economic resources have a greater capacity to respond. Belonging to a social organization is also significantly related to resilience. It is easier to face all kinds of externalities of the agroecosystem if you belong to an organization that can offer support in such circumstances (Aguilar et al., 2012).

Farm infrastructure did not show a significant relationship with resilience. It should be noted that the farms had an average infrastructure between medium and high, at 62\% (Mateus et al., 2012).

Water resource availability showed no significant relationship with resilience, possibly because precipitation supplies the crop's water requirement. However, having a source of water for irrigation increases the resilience of the agroecosystem (Cleves-Leguizamo et al., 2016; Reay, 2019).

Cultural variables such as Phytosanitary Management and Weed control are related to resilience. Both contribute to better crop management in the face of adverse externalities fundamentally associated with disturbances linked to change and climatic variability (Quintero-Pertuz and Carbonó-Delahoz, 2015; Reay, 2019). Such changes, although resulting from internal natural processes (radiative forcing) as well as anthropogenic activities that affect the composition of the atmosphere, are fundamentally changes in land use and soil vocation (Pabón and Hurtado, 2002; IPCC, 2001; IPCC, 2007; IPCC, 2013).

This situation is relevant in Colombia because of its geodetic position, which makes it vulnerable to the occurrence of meteorological phenomena more than any other country in the region. Temperature and precipitation variations affect crop yield with a greater intensity in long-cycle crops such as citrus (Naciones Unidas, 1992; Boshell et al., 2011; ClevesLeguizamo et al., 2016).

The Production System was significantly related to resilience since the biodiversity of the productive system contributes differentially to the resilience of the agroecosystem, in accordance with the results obtained by Altieri and Nicholls (2013). The authors reported that biodiversity agroecosystems are more resilient. 
The Main Agroecological Structure did not present a statistically significant relationship with resilience because this index does not describe the complexity of productive systems (León-Sicard et al., 2018).

Belonging to a social organization and resilience showed a statistically significant relationship. This result showed that the characterization and typing prior to the study allowed an accurate grouping of the farms (Cleves-Leguizamo and Jarma-Orozco, 2014).

The value of farm resilience was related to group resilience, highlighting the consistency of the resilience results for each of the farms and groups.

\section{Analysis of resilience between groups}

To determine differences between the groups, an ANOVA was performed. This test showed that there were significant statistical differences between the groups, with a 95\% confidence level (Tab. 7). Once it was determined that there was a statistical difference, multiple comparison tests (Duncan, Tukey and Dunnet) were carried out to establish clusters and differences between the groups. The results are shown below (Tab. 8 and 9).

Table 7. Analysis of variance of resilience by farm groups.

\begin{tabular}{|l|c|c|c|c|c|}
\hline & Grades & $\begin{array}{c}\text { Sum of } \\
\text { squares }\end{array}$ & $\begin{array}{c}\text { Quadratic } \\
\text { mean }\end{array}$ & $F$ & $\operatorname{Pr}>F$ \\
\hline Model & 5 & 17.273 & 3.454 & 12.54 & 0.0002 \\
\hline Error & 12 & 3.306 & 0.275 & & \\
\hline Total & 17 & 20.580 & & & \\
\hline
\end{tabular}

The Duncan test was used to compare all pairs of means. This does not require a previous $\mathrm{F}$ test, as does DMS, so it can be carried out without the F test. On the other hand, the Tukey test uses a single value with which all possible pairs of means are compared. Finally, in the Dunnet test, the means are compared against the control group. The results of the Duncan and Tukey test are in Tab. 8, and the results of the Dunnet test are in Tab. 9.

The test results confirmed that group 4 had the highest level of resilience; group 6 had the lowest; groups 2, 3 and 5 had a medium level of resilience; and there were no significant differences between group 1 and group 6.

\section{Table 8. Duncan and Tukey test results for resilience by} farm/group.

\begin{tabular}{|c|c|c|c|c|}
\hline Group & Half Static & Duncan's Grouping & \multicolumn{2}{|c|}{ Tukey Grouping } \\
\hline 4 & 4.73 & A & A & \\
\hline 5 & 3.70 & B & A & B \\
\hline 3 & 3.56 & C & A & B \\
\hline 2 & 3.16 & D & & B \\
\hline 1 & 2.70 & E & C & B \\
\hline 6 & 1.53 & F & C & \\
\hline
\end{tabular}

Table 9. Dunnet test results for resilience by farm group.

\begin{tabular}{|c|c|c|c|c|c|}
\hline \multicolumn{2}{|c|}{$\begin{array}{c}\text { Comparison } \\
\text { group }\end{array}$} & $\begin{array}{c}\text { Difference } \\
\text { between means }\end{array}$ & \multicolumn{3}{c|}{ Confidence limits } \\
\hline 4 & 6 & 3.20 & 1.95 & 4.44 & $* * *$ \\
\hline 5 & 6 & 2.16 & 0.92 & 3.41 & $* * *$ \\
\hline 3 & 6 & 2.03 & 0.78 & 3.27 & $* * *$ \\
\hline 2 & 6 & 1.63 & 0.38 & 2.87 & $* * *$ \\
\hline 1 & 6 & 1.16 & -0.07 & 2.41 & \\
\hline
\end{tabular}

*** indicates comparisons were significant at the $P \leq 0.05$ level.

The differences found with the various means comparison techniques between the groups were consistent with the initial categories determined at the start of the study, indicating that the typing was correct. Likewise, the socio-ecological variables characterized the agroecosystems, which correctly determined the resilience at the farm and group level (Folke, 2006).

\section{Variable correlation matrix}

To determine the degree of relationship between the variables, 78 Pearson's Chi-squared and Fisher's exact tests were performed in the SPSS statistical program. Fisher's test was used to determine relationships between variables since it is used for small samples. In all cases, a 95\% confidence level was used along with a null hypothesis of independence between the variables (Tab. 10).

From this matrix, a network diagram was developed using the NetDraw program, where the size of the nodes represented the number of relationships between the variables used to calculate resilience (Fig. 6).

The resilience of a farm was related to the variables Savings capacity, Production system, Belonging to a social 
organization, Phytosanitary management, Weed control, Type of land tenure, and Group resilience. While the Education level, Availability of water resources, Farm infrastructure and Main agroecological structure were not related to resilience at the farm level.
These results show that the practices and characteristics of the productive unit are determining factors in socio-ecological resilience; the statistical analysis that supports this statement will be presented later (León-Sicard et al., 2018) (Tab. 10).

Table 10. Summary of Chi-squared test results for variables used in the evaluation of socio-ecological resilience.

\begin{tabular}{|l|l|l|l|l|l|l|l|l|l|l|l|l|l|}
\hline & NIDES & TEDLT & CAPDA & TIDOR & INDLF & FDAPR & EVSDC & CODAR & SIDPR & MAS & RESFI & RESGR & GRUP0 \\
\hline NIDES & 1.000 & 1.000 & 0.819 & 0.032 & 0.769 & 0.272 & 0.520 & 0.415 & 0.071 & 0.056 & 0.087 & 0.029 & 0.046 \\
\hline TEDLT & & 1.000 & 1.000 & 0.216 & 0.010 & 0.056 & 0.010 & 0.025 & 0.515 & 0.113 & 0.001 & 0.004 & 0.007 \\
\hline CAPDA & & & 1.000 & 0.638 & 0.566 & 1.000 & 0.759 & 0.387 & 0.054 & 0.775 & 0.037 & 0.878 & 0.961 \\
\hline TIDOR & & & & 1.000 & 0.904 & 0.216 & 0.030 & 0.018 & 0.002 & 0.131 & 0.004 & 0.026 & 0.134 \\
\hline INDLF & & & & & 1.000 & 0.357 & 0.095 & 0.012 & 0.257 & 0.129 & 0.095 & 0.031 & 0.006 \\
\hline FDAPR & & & & & & 1.000 & 0.010 & 0.326 & 0.515 & 0.382 & 0.051 & 0.070 & 0.338 \\
\hline EVSDC & & & & & & & 1.000 & 0.024 & 0.106 & 0.358 & 0.024 & 0.031 & 0.117 \\
\hline CODAR & & & & & & & & 1.000 & 0.150 & 0.143 & 0.004 & 0.037 & 0.103 \\
\hline SIDPR & & & & & & & & & 1.000 & 0.055 & 0.000 & 0.044 & 0.175 \\
\hline MAS & & & & & & & & & & 1.000 & 0.177 & 0.000 & 0.005 \\
\hline RESFI & & & & & & & & & & & 1.000 & 0.003 & 0.012 \\
\hline RESGR & & & & & & & & & & & & 1.000 & 0.000 \\
\hline GRUPO & & & & & & & & & & & & & 1.000 \\
\hline
\end{tabular}

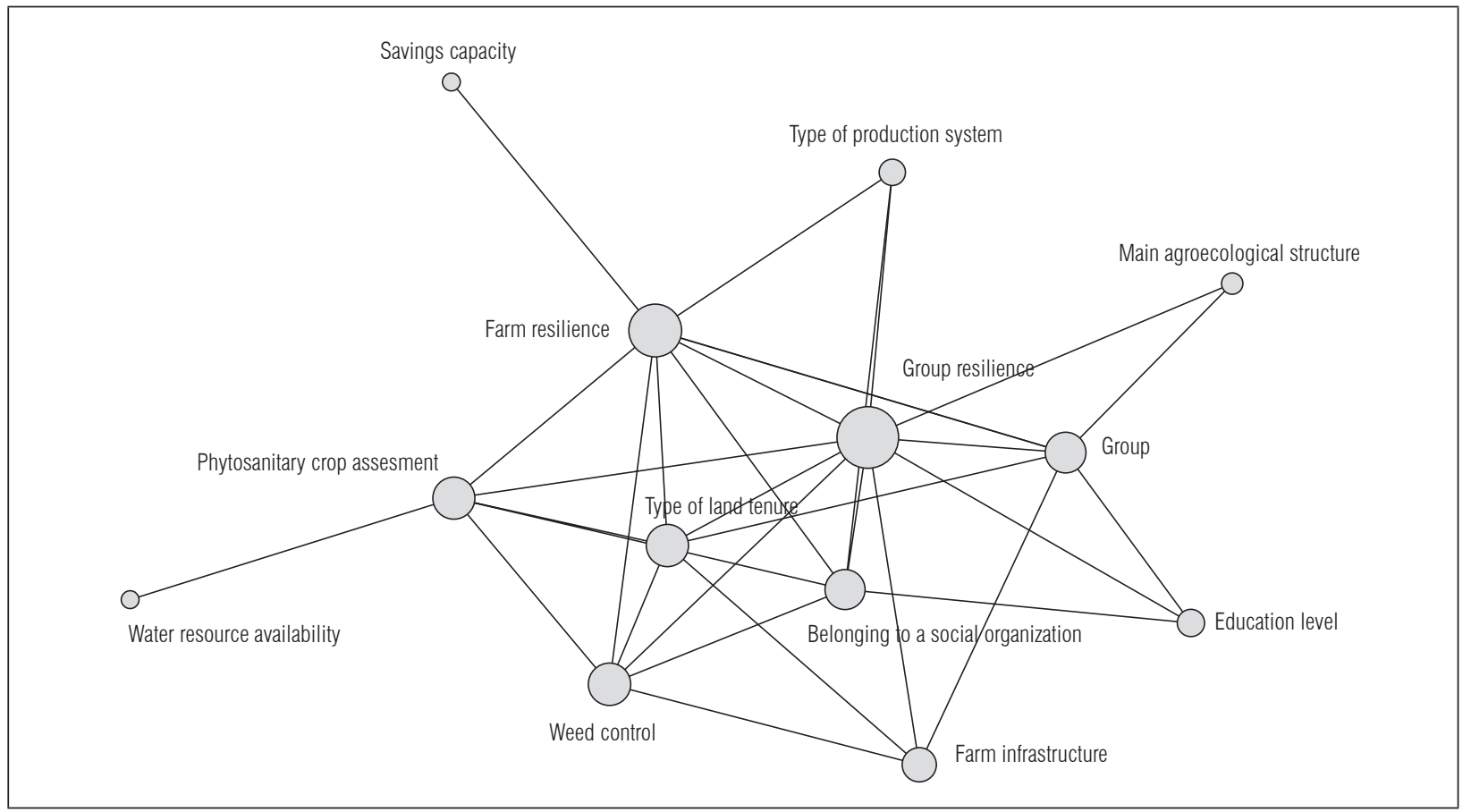

Figure 6. Network of interactions between variables used for the evaluation of socio-ecological resilience. 
These results corresponded to the Fisher's and Pearson tests, and indicated that the socio-ecological resilience of citrus producers in the Department of Meta is influenced by the variables that directly affect the productivity of the crop, as well as by the relationships and economic capacity of the producer (Mateus et al., 2010), which allow them to make up for the deficiencies they may have individually, for example in terms of education, training, availability of infrastructure and technical assistance (Aguilar et al., 2012).

The variable Farm infrastructure was related to Type of land tenure, Weed control, Group and Group level resilience. Farm infrastructure was related to farm resilience in the network chart although it was not statistically significant according to the Fisher's and Pearson's tests. For group resilience, physical capital was important to better assimilating externalities derived from climate change and its variability.

The $M A S$ variable was only related to resilience at the group level. As mentioned, it was strongly marked by ecological attributes related to agroecosystem arrangements, rather than with cultural variables (Cleves-Leguizamo, 2018b).

The Availability of water resources was only related to Phytosanitary management, and Savings capacity was only related to farm resilience. These variables only had a relationship in the interaction network (Reay, 2019).

This analysis allows us to infer that variables such as: Phytosanitary management, Weed control and Production system are useful tools for the implementation of union actions that contribute to the technical improvement of citrus crops in the region (Orduz and Mateus, 2012).

Finally, variables such as: Phytosanitary management, Weed control and Production system, which presented a significant relationship with resilience, are useful tools for the implementation of union actions that contribute to the technical improvement of citrus crops in the region (Cleves-Leguizamo et al., 2012; Orduz, and Mateus, 2012).

The variables Type of land tenure, Savings capacity and Belonging to an organization can also be key aspects for the implementation of sociocultural actions that can benefit citrus producers in the Department of Meta.
It is important to note that these relationships are represented in terms of the values of statistical significance, which is calculated from the sample data, so, for larger samples, established relationships could eventually vary (Cleves-Leguizamo, 2018a).

\section{CONCLUSIONS}

Cultural variables, in other words those determined by human actions, present the highest statistical significance in their relationship with resilience.

The variables Education level, Farm infrastructure, Availability of water resources and MAS did not show a significant relationship with resilience.

The behavior of the groups characterized and typified in this study was consistent with respect to resilience, confirming the differences between them and validating the characteristics of the recommendation domains.

Since the internal consistency of the groups has been confirmed, strategies can be proposed by virtue of the internal homogeneity of the groups and, in turn, the heterogeneity between them.

The variables included in this study presented between one (1) and ten (10) interactions, confirming the systemic nature of the developed analysis.

The MAS did not present a statistically significant relationship with resilience because this index, despite analyzing five ecosystem attributes and five cultural attributes, failed to describe the complexity of productive systems reliably, mainly because it did not evaluate fundamental attributes such as availability of water resources and edaphic aptitude.

Conflict of interest: this manuscript was prepared and reviewed with the participation of all authors, who declare that there exists no conflict of interest that that puts at risk the validity of the presented results.

\section{BIBLIOGRAPHIC REFERENCES}

Adger, N. 2000. Social and ecological resilience: are they related? Prog. Hum. Geogr. 24(3), 347-364. Doi: 10.1191/030913200701540465 
Aguilar, P., M. Escobar, and C. Carvalho. 2012. Situación actual de la cadena de cítricos en Colombia: limitantes y perspectivas. pp. 7-48. In: Cítricos: Cultivo, poscosecha e industrialización. Corporación Universitaria Lasallista, Caldas, Colombia.

Altieri, M., F. Funes, A. Henao, C. Nicholls, T. León, L. Vázquez, and G. Zuluaga. 2012. Hacia una metodología para la identificación, diagnóstico y sistematización de sistemas agrícolas resilientes a eventos climáticos extremos. Red Iberoamericana de Agroecología Para el Desarrollo de Sistemas Agrícolas Resilientes al Cambio Climático-Redagres, Bogota.

Altieri, M. and C.I. Nicholls. 2013. Agroecología y resiliencia al cambio climático: principios y consideraciones metodológicas. Agroecología 8(1), 7-20.

Borgatti, S.P., M.G. Everett, and L.C. Freeman. 2002. Ucinet for Windows: software for Social Network Analysis. Analytic Technologies, Harvard, MA.

Boshell, J., G. León, and A. Peña. 2011. Contextualización de los efectos del cambio climático en la agricultura. Serie Manual 3 GIZ, Perú.

Cleves-Leguizamo, J.A., J. Fonseca, and J. Orduz. 2012. Aportes de la investigación en cítricos al manejo agroecológico del cultivo en el piedemonte del departamento del Meta, Colombia. Rev. Investig. Agrar. Ambient. 2(3), 85-97. Doi: 10.22490/21456453.945

Cleves-Leguizamo, J.A. and J. Jarma-Orozco. 2014. Characterization and typification of citrus production systems in the department of Meta. Agron. Colomb. 32(1), 113-121. Doi: 10.15446/agron.colomb. v32n1.42164

Cleves-Leguizamo, J.A., J. Toro-Calderón, and L. Martínez-Bernal. 2016. Los balances hídricos agrícolas en modelos de simulación agroclimáticos. Una revisión analítica. Rev. Colomb. Cienc. Hortic. 10(1), 149-163. Doi: 10.17584/rcch.2016v10i1.4460

Cleves-Leguizamo, J.A., J. Toro-Calderón, L. Martínez-Bernal, and T. León. 2017. La Estructura Agroecológica Principal (EAP): novedosa herramienta para la planeación del uso de la tierra en agroecosistemas. Rev. Colomb. Cienc. Hortic. 11(2), 441-449. Doi: 10.17584/ rcch.2017v11i2.7350

Cleves-Leguizamo, J.A. 2018a. Resiliencia de los agroecosistemas citrícolas a la variabilidad climática en el departamento del Meta, Colombia. $\mathrm{PhD}$ tesis. Doctorate in Agroecology, Faculty of Agricultural Sciences, Universidad Nacional de Colombia, Bogota.

Cleves-Leguizamo, J.A. 2018b. Avances conceptuales y metodológicos de la construcción de la Estructura Agroecológica Principal (EAP) de los agroecosistemas. Editorial UPTC, Tunja, Colombia.

Farhad, S. 2012. Los sistemas socioecológicos, una aproximación conceptual y metodológica. In: Proc. Conference XIII Jornadas de Economía Crítica. Oviedo, Spain.
Folke, C. 2006. Resilience: the emergence of a perspective for social-ecological systems analysis. Glob. Environ. Change 16(3), 253-267. Doi: 10.1016/j. gloenvcha.2006.04.002

Hart, R. 1985. Conceptos básicos sobre agroecosistemas. Centro Agronómico Tropical de Investigación y Enseñanza-CATIE, Turrialba, Costa Rica.

Henao, A. 2013. Propuesta metodológica de medición de la resiliencia agroecológica en sistemas socio-ecológicos: un estudio de caso en los Andes colombianos. Agroecología 8(1), 85-91.

Holling, C.S. 2001. Understanding the complexity of economic, ecological, and social systems. Ecosystem 4(5), 390-405. Doi: 10.1007/s10021-001-0101-5

IGAC, Instituto Geográfico Agustín Codazzi. 2004. Levantamiento general de suelos del departamento del Meta. Subdirección de Agrología, Bogota.

IPCC, Intergovernmental Panel on Climate Change. 2001. Cambio Climático 2001 "informe de síntesis". Geneva, Switzerland.

IPCC, Intergovernmental Panel on Climate Change. 2007. Cambio Climático 2007 "Informe de síntesis del cuarto informe de evaluación". Geneva, Switzerland.

IPCC, Intergovernmental Panel on Climate Change. 2013. Cambio Climático 2013 "bases físicas": Informe del Grupo de trabajo I. Geneva, Switzerland.

Jiggins, J. and N. Rölling. 2000. Adaptive management: potential and limitations for ecological governance. Int. J. Agric. Resour. Gov. Ecol. 1(1), 28-42.

León, T. and M. Altieri. 2009. Enseñanza, investigación y extensión en agroecología: la creación de un Programa de Doctorado Latinoamericano en Agroecología. Sociedad Española de Agricultura Ecológica / Agroecología, Valencia, Spain.

León, T. 2010. Regulación biológica en agricultura de pequeña escala: un enfoque desde la sostenibilidad. pp. 271-293. In: León, T. and M. Altieri (eds.). Vertientes del pensamiento agroecológico: fundamentos y aplicaciones. IDEA, Universidad Nacional de Colombia, Bogota.

León, T. 2012. Agroecología: la ciencia de los agroecosistemas - la perspectiva ambiental. IDEA, Universidad Nacional de Colombia, Bogota.

León-Sicard, T.E., J. Toro-Calderón, L.F. Martínez-Bernal, and J.A. Cleves-Leguizamo. 2018. The main agroecological structure (MAS) of the agroecosystems: concept, methodology and applications. Sustainability 10(9), 3131. Doi: 10.3390/su10093131

Mateus, D., X. Pulido, A. Gutiérrez, and J. Orduz. 2010. Evaluación económica de la producción de cítricos cultivados en el piedemonte del departamento del Meta durante 12 años. Orinoquia 14(1), 16-26. 
Maya, A. 2003. Pensamiento ambiental. La diosa Némesis: desarrollo sostenible o cambio cultural. Vol. 2. Corporación Universitaria Autónoma de Occidente, Cali, Colombia.

MEA, Millennium Ecosystem Assessment. 2005. Ecosystems and human Well-Being. Island Press, Washington, DC.

Naciones Unidas. 1992. Convención marco de la Naciones Unidas sobre el cambio climático. FCCC/INFORMAL/84. Rome.

Nicholls, C.I. and M.A. Altieri. 2012. Estrategias agroecológicas para incrementar la resiliencia. Rev. Agroecología Leisa 28(2), 14-17.

Orduz, J. and D. Mateus. 2012. Generalidades de los cítricos y recomendaciones agronómicas para su cultivo en Colombia. pp. 49-88. In: Cítricos: Cultivo, poscosecha e industrialización. Corporación Universitaria Lasallista, Caldas, Colombia.

Pabón, J., J. Eslava-Ramírez, and R. Gómez-Torres. 2001. Generalidades de la distribución espacial y temporal de la temperatura del aire y de la precipitación en Colombia. Meteorol. Colomb. 4, 47-59.

Pabón, J. and G. Hurtado. 2002. La variabilidad y el cambio climático y su efecto en los biomas de páramo. pp. 98-209. In: Proc. Congreso Mundial de Páramos.
Tomo 1. Ministerio del Medio Ambiente; Corporación Autónoma Regional de Cundinamarca; Instituto de Hidrología, Meteorología y Estudios Ambientales; Conservación Internacional Colombia, Bogota.

PNUD, Programa de la Naciones Unidas para el Desarrollo. 2011. Impacto de la variabilidad climática sobre la seguridad alimentaria en Colombia. Bogota.

Quintero-Pertúz, I. and E. Carbonó-Delahoz. 2015. Panorama del manejo de malezas en cultivos de banano en el departamento de Magdalena, Colombia. Rev. Colomb. Cienc. Hortic. 9(2), 329-340. Doi: 10.17584/ rcch.2015v9i2.4188

Reay, D. 2019. Climate-smart orange juice. pp. 9-19. In: Climate-smart food. Palgrave Pivot, Cham, Switzerland. Doi: 10.1007/978-3-030-18206-9_2

SDA, Secretaría de Desarrollo Agroeconómico. 2016. Cifras agropecuarias. Gobernación del Meta, Villavicencio, Colombia.

Toledo, V. 1999. Modernidad y ecología: la nueva crisis planetaria. Ecol. Polít. 3, 9-22.

Walker, B., C.S. Holling, S.R. Carpenter, and A. Kinzig. 2004. Resilience, adaptability and transformability in social-ecological systems. Ecol. Soc. 9(2), 5. Doi: 10.5751/ES-00650-090205 